\title{
POLLEN NATURAL RESOURCES FOR BEES IN SLOVAKIA
}

\section{Chlebo Róbert ${ }^{1}$, Adamchuk Leonora ${ }^{2 *}$}

\author{
${ }^{1}$ Slovak University of Agriculture in Nitra, Slovak Republic \\ ${ }^{2}$ National University of Life and Environmental Sciences of Ukraine, Kyiv, Ukraine \\ Received 25. 6. 2017 \\ Revised 29. 6. 2017 \\ Published 25.11.2017
}

Studying the pollen resources is a topical issue for both honey bees and people. The aim of our work was pollen natural resources for bees in deferent regions of Slovakia. Pollen grains, bee pollen, bee families and certain species of enthomophile plants served as a biological material. Flowering terms and other information related to the use of protein feed by bees in different regions of Slovakia were obtained after processing the information gained from local beekeepers. The bee pollen was selected several times a month in a set period that was the same for Trenčín, Banská Bystrica, Prešov, Bratislava and Nitra regions. Flower pollen resources were not of the same botanical origin for different regions of Slovakia. Percentage of pollen resources available for bees from different of plants species were established for each region. The definitions were made using pollen analysis of the bee pollen brought by the bees to their homes in the spring and summer periods and also in different decades of months from May to September. Significant resources of flower pollen are characteristic of than Slovak regions of the total: during spring in Trenčín are Robinia spp. - 31\%; during spring are Salicaceae - 52\% and summer are Helianthus spp. - 64\%; during spring in Prestavlky Rosaceae - 42\% and summer Brassicaceae - 70\%; during spring in Spišský Štiavnik are Salicaceae $-70 \%$ and summer: Helianthus spp. - 56\%; during spring in Hranivnica are Salicaceae $60 \%$ and summer Epilobium spp. - 90\%; during spring in Bratislava are Malus spp. $-35 \%$ and summer Helianthus spp. $-46 \%$.

Keywords: flower pollen; pollen resources; bee pollen; Slovakia

\section{Introduction}

Scientists have researched nectar and pollen resources for stingless bees (Meliponinae, Hymenoptera) in South America (Engel and Dingemans-Bakels, 1980). They found the most important food plants for stingless bees are: Avicennia germinans, Aciotes dichotoma, Syzygium cumini, Polyganum acuminatum and Solanum species. The research of pollen resources for honeybees has been carried out in many countries (Corbet et al., 1991; Biesmeijer et al., 2006; Hilgert-Moreira et al., 2013; Di Pasquale et al., 2016).

Established the farming system had the greatest influence on biodiversity. Higher bee diversity, flower cover, and diversity of flowering plants were recorded in organic compared with conventional fields. Bee diversity was related both to flower cover and diversity of flowering plants, suggesting plantmediated effects of the farming system. Namely, higher bee diversity, flower cover, and diversity of flowering plants were recorded in organic compared with conventional fields. Scientists argue than bee diversity was related both to flower cover and diversity of flowering plants, suggesting plant-

*Corresponding author: Leonora Adamchuk, National University of Life and Environmental Sciences of Ukraine, Kyiv, Ukraine, $\triangle$ leonora.adamchuk@gmail.com 
mediated effects of the farming system (Benton, et al., 2003; Bengtsson et al., 2005; Holzschuh et al., 2007).

The resources of pollen under restricted feed conditions and affect honey bee health are found (Naug, 2009; Decourtye et al., 2010; Hilgert-Moreira et al., 2013; Danner et al., 2014).

It is generally known that the quantity and quality of pollen affect the condition and development of bee families (Carreck and Williams, 2002; Aizen and Harder, 2009; Alaux et al., 2010). Also, has already been set that the pollen botanical origin of an affects the morphological and biochemical features of a bee pollen as a food for people (Grygorieva et al., 2015; Адамчук і Акульонок, 2016; Novytska et al., 2016; Redina, et al., 2016). So, studying the pollen resources is a topical issue for both honey bees and people. Therefore, the aim of our work was pollen natural resources for bees in deferent regions of Slovakia.

\section{Materials and methodology}

Scientific issues that were set up during the research have been solved experimentally, using the next methods of research: zootechnical (setting experiments, pollen productivity, selection of bee pollen), microscopical (analysis of pollen), statistical (biometrical data processing) and analytical (literature review, analysis and generalization of the results of research).

Pollen grains, bee pollen, bee families and certain species of enthomophile plants served as a biological material. Experimental samples were collected during the period of training from 2015 to 2017 in deferent regions in Slovakia. Flowering terms and other information related to the use of protein feed by bees in different regions of Slovakia were obtained after processing the information gained from local beekeepers. The bee pollen was selected several times a month in a set period that was the same for all regions.

Online database PalDat and personal developments served as information media. Next software resources have been used: statistical programs, graphic editor Paint.Net 4.0.

\section{Results and discussion}

Flower pollen resources were not of the same botanical origin for different regions of Slovakia. In Trenčín region tradable bee pollen was obtained only during spring. Biodiversity of the resources for its production are, \%: Robinia spp. - 31, Salicaceae - 17, Rosaceae - 14, Brassicaceae - 13, Poaceae 11, Loranthus europeus Jacq. - 8, Asteraceae - 4, Aceraceae - 2.

In Banská Bystrica region the research was carried out in two areas - Lesenice and Prestavlky. During spring season in Lesnice the resources of bee pollen were represented with the next species, \%: Salicaceae - 52; Brassicaceae - 50; Asteraceae - 6; Aceraceae - 17; Rosaceae - 10; Apiaceae - 15; Robinia spp. - 15-35.

During the summer period the pollen resources in Lesenice were represented with a bigger number of species, \%: Salicaeae - 5-6; Brassicaceae - 44-48; Asteraceae - 8-66; Aceraceae - 2-5; Rosaceae 9; Fabaceae - 4-35; Poaceae - 5; Apiaceae - 8-16; Helianthus spp. - 2-64; Robinia spp. - 6; Vicia spp. - 35; Lamiaceae - 2-29; Taraxacum spp. - 5-20; Achillea spp. - 20; Cirsium spp. - 20; Tiliaceae - 5. The example throughout the Lesenice, Banská Bystrica region is shown in Table 1. 
Table 1 Variety of the pollen resources available for bees in Slovakia, \%

\begin{tabular}{|c|c|c|c|c|c|c|c|c|}
\hline \multirow[t]{2}{*}{ Family, genus } & \multicolumn{8}{|c|}{ Accounting period, decade } \\
\hline & $\begin{array}{l}3 \text { of } \\
\text { May }\end{array}$ & $\begin{array}{l}2 \text { of } \\
\text { May }\end{array}$ & $\begin{array}{l}1 \text { of } \\
\text { June }\end{array}$ & $\begin{array}{l}3 \text { of } \\
\text { June }\end{array}$ & $\begin{array}{l}2 \text { of } \\
\text { July }\end{array}$ & $\begin{array}{c}1 \text { of } \\
\text { August }\end{array}$ & $\begin{array}{c}3 \text { of } \\
\text { August }\end{array}$ & $\begin{array}{c}2 \text { of } \\
\text { September }\end{array}$ \\
\hline Salicaeae & 52 & & & 5 & & 6 & & \\
\hline Brassicaceae & & 50 & 48 & 44 & & & & \\
\hline Asteraceae & 6 & & 8 & 19 & & 15 & & 66 \\
\hline Aceraceae & 17 & & 2 & 5 & & & & \\
\hline Rosaceae & 10 & & & & & & & 9 \\
\hline Fabaceae & & & & 9 & & 4 & 35 & 20 \\
\hline Poaceae & & & 5 & & & & & \\
\hline Apiaceae & & 15 & & 16 & 8 & & & \\
\hline Helianthus spp. & & & & 2 & 63 & 64 & 5 & \\
\hline Robinia spp. & 15 & 35 & & & & 6 & & \\
\hline Vicia spp. & & & 35 & & & & & \\
\hline Lamiaceae & & & 2 & & 29 & & & \\
\hline Taraxacum spp. & & & & & & 5 & 20 & \\
\hline Achillea spp. & & & & & & & 20 & \\
\hline Cirsium spp. & & & & & & & 20 & \\
\hline Tiliaceae & & & & & & & 5 & \\
\hline
\end{tabular}

The general scheme of the pollen resource supply in some regions of Slovakia is shown in Figure 1.

During spring in Prestavlky the resources of bee pollen were represented with the next species, \%: Salicaceae - 36; Rosaceae - 30-42; Aceraceae - 23-15; Robinia spp. - 11-15; Lamiaceae - 12; Apiaceae - 8; Brassicaceae - 5; Fabaceae - 3. During summer, \%: Salicaeae - 5; Rosaceae - 7; Aceraceae - 3; Apiaceae - 4-14; Brassicaceae - 5-70; Fabaceae - 3-50; Poaceae - 8-11; Asteraceae 21-59; Tiliaceae - 3-15; Zea mays L. subsp. mays - 4-45; Taraxacum spp. - 5; Alliaceae - 7-20; Helianthus spp. -3.

In Prešov region, the results were obtained from two areas - Spišský Štiavnik and Hranovnica. During spring period in Spišský Štiavnik the resources for bee pollen production were represented with the next species, \%: Salicaceae - 70; Brassicaceae - 10; Asteraceae - 9-35; Aceraceae - 7-27; Prunus spp.- 4; Rosaceae - 20; Fabaceae - 18. During summer, \%: Salicaeae - 4-8; Brassicaceae - 5-40; Asteraceae - 9-39; Aceraceae - 7-27; Rosaceae - 20; Fabaceae - 13-39; Poaceae - 3-14; Apiaceae 2-15; Helianthus spp.- 5-56; Phacelia spp. - 50.

In Hranovnica during spring period the next sources of pollen were represented, \%: Salicaceae 7-60; Brassicaceae - 25; Asteraceae - 15; Robinia spp. - 35; Aceraceae - 25; Epilobium spp. - 20; Tiliaceae - 7; Ericaceae - 4; Pinus spp. - 2. During summer, \%: Salicaeae - 40; Asteraceae - 4-44; Robinia spp. - 20; Aceraceae - 13; Epilobium spp. - 20-90; Tiliaceae - 2-4; Ericaceae - 9; Pinus spp. - 1; Rosaceae - 13; Fabaceae - 18-46; Apiaceae - 10; Poaceae - 10; Helianthus spp. - 5; Lamiaceae - 4. 


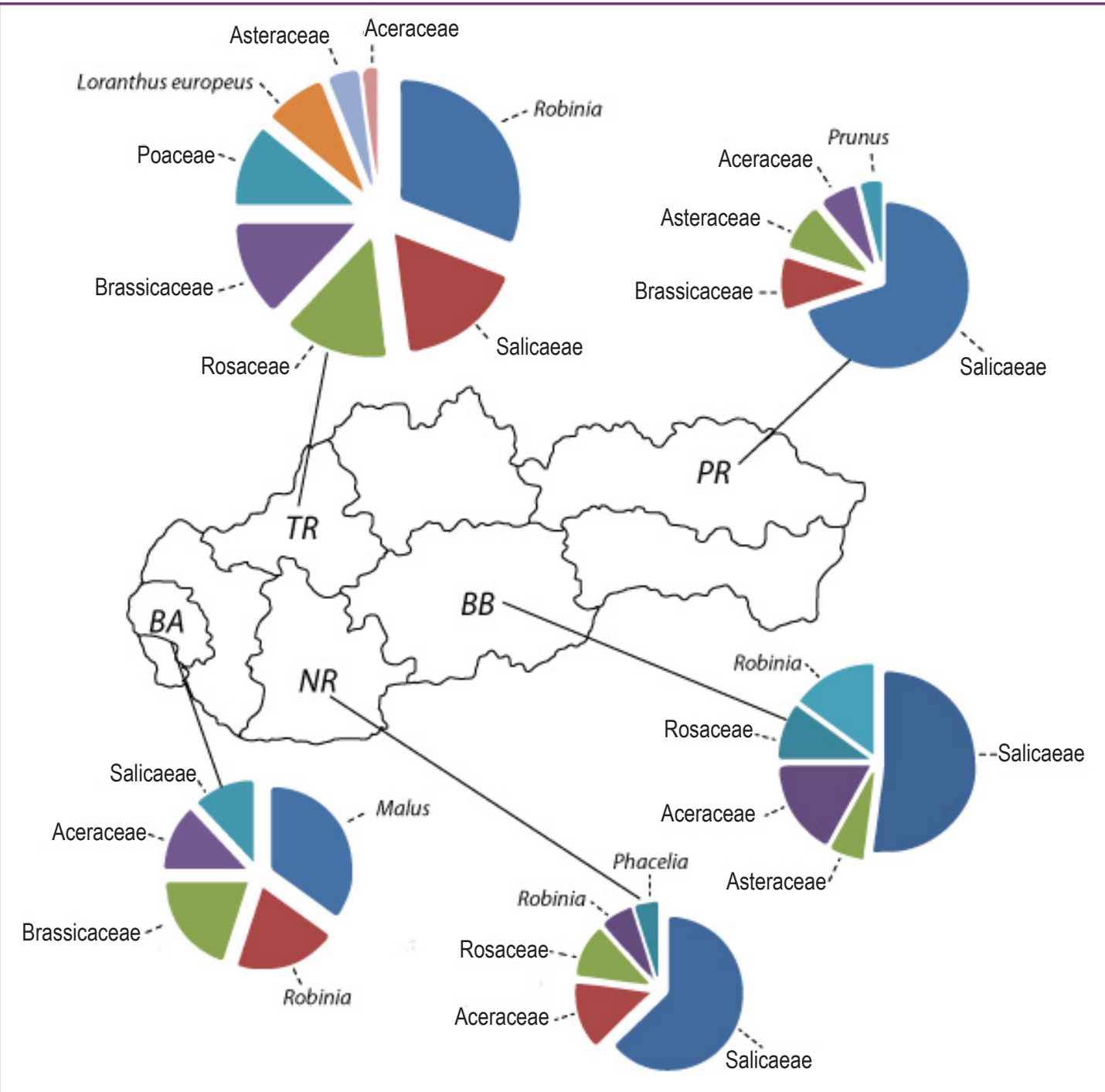

Figure 1 Pollen resources supply in some regions of Slovakia

In Bratislava region, minor resources of pollen (\%) were established, which during spring period were represented with Malus spp. - 35, Robinia spp. - 20, Brassicaceae - 20, Aceraceae - 13, Salicaceae - 12. During summer, \%: Helianthus spp. - 46, Cirsium spp. - 39, Poaceae - 5, Zea mays L. subsp. mays - 5, Fabaceae - 5 .

In Nitra region during spring season the pollen was produced by such species, \%: Salicaeae - 11-63; Aceraceae - 14-25; Rosaceae - 11-44; Robinia spp. - 7-15; Phacelia spp. - 5; Brassicaceae - 20-38; Asteraceae - 11. During summer, \%: Rosaceae - 12; Robinia spp. - 13; Phacelia spp. - 35; Brassicaceae 5-25; Asteraceae - 28-46; Vicia spp. - 15; Fabaceae - 10-32; Tiliaceae - 4-15; Poaceae - 3-7; Helianthus spp. - 3-37; Zea mays L. subsp. mays - 6; Chenopodiaceae - 30; Campanulaceae - 5. 


\section{Conclusions}

Significant resources of flower pollen are characteristic of than Slovak regions of the total: during spring in Trenčín are Robinia spp. - 31\%, Salicaceae - 52\% and summer are Helianthus spp. - 64\%; during spring in Prestavlky is Rosaceae - 42\% and summer is Brassicaceae - $70 \%$; during spring in Spišský Štiavnik are Salicaceae - 70\% and summer are Helianthus spp. - 56\%; during spring in Hranivnica are Salicaceae $-60 \%$ and summer are Epilobium spp. - 90\%; during spring in Bratislava are Malus spp. $-35 \%$ and summer are Helianthus spp. $-46 \%$.

\section{Acknowledgments}

Co-author Leonora Adamchuk thanks the International Visegrad Fund for scholarship and research internships, during which were getting the results and knowledge presented in this paper.

\section{References}

Adamchuk, L., Samoilenko, V., Nikolaieva, N. 2016. Morphological characteristics of Corylus avellana L. bee pollen. Збірник БНАУ: Серія Технологія виробництва і переробки продукції тваринництва, № 2, c. 47-51.

Aizen, M.A., Harder, L.D. 2009. The global stock of domesticated honey bees is growing slower than agricultural demand for pollination. Curr. Biol., vol. 19, p. 915-918.

Alaux, C., Ducloz, F., Crauser, D., Le Conte, Y. 2010. Diet effects on honeybee immunocompetence. Biology Letters, vol. 6, no. 4, p. 562-565. DOl: 10.1098/rsbl.2009.0986

Bengtsson,J.,Ahnström,J.,Weibull,A.C.2005.Theeffectsoforganicagricultureonbiodiversityandabundance: a meta-analysis. Journal of Applied Ecology, vol. 42, p. 261-269. DOI: 10.1111/j.1365-2664.2005.01005.x

Benton, T.G., Vickery, J.A., Wilson, J.D. 2003. Farmland biodiversity: is habitat heterogeneity the key? Trends in Ecology and Evolution, vol. 18, p. 182-188. DOI: http://dx.doi.org/10.1016/S0169-5347(03)00011-9

Biesmeijer, J.C., Roberts, S.P.M., Reemer, M., Ohlemuller, R., Edwards, M., Peeters, T., Schaffers, A.P., Potts, S.G., Kleukers, R., Thomas, C.D., Settele, J., Kunin, W.E. 2006. Parallel declines in pollinators and insect-pollinated plants in Britain and the Netherlands. Science, vol. 313, p. 351-354. DOI: 10.1126/ science. 1127863

Brovarskij, V., Brindza, J. a i. 2010. Včelí obnôžkový pel.' Maidachenko : FOP IS.

Carreck, N.L., Williams, I.H. 2002. Food for insect pollinators on farmland: insect visits to flowers of annual seed mixtures. J. Insect Conserv., vol. 6, p. 13-23. DOI: 10.1023/A:1015764925536

Corbet, S.A., Williams, I.H., Osborne J.L. 1991. Bees and the pollination of crops and wild flowers in the European community. Bee World, vol. 71, p. 47-59. http://dx.doi.org/10.1080/0005772X.1991.11099079

Danner, N., Härtel, S., Steffan-Dewenter, I. 2014. Maize pollen foraging by honey bees in relation to crop area and landscape context. Basic and Applied Ecology, vol. 15, no. 8, p. 677-684. DOI: 10.1016/j. baae.2014.08.010

Decourtye, A., Mader, E., Desneux, N. 2010. Landscape enhancement of floral resources for honey bees in agro-ecosystems. Apidologie, vol. 41, no. 3, p. 264-277. DOI: 10.1051/apido/2010024

Di Pasquale, G., Alaux, C., Le Conte, Y., Odoux, J.F., Pioz, M., Vaissière, B.E., Belzunces, L.P., Decourtye, A. 2016. Variations in the availability of pollen resources affect honey bee health. PloS one, vol. 11, no. 9, e0162818. DOI: 10.1371/journal.pone.0162818

Engel, M.S., Dingemans-Bakels, F. 1980. Nectar and pollen resources for stingless bees (Meliponinae, Hymenoptera) in Surinam (South America). Apidologie, vol. 11, no. 4, p. 341-350. DOI: 10.1051/ apido:19800402

Grygorieva, O., Nikolaieva, N., Brindza, J., Klymenko, S. 2015. Pollen and bee pollen features of sweet chestnut (Castanea sativa Mill.). Науковий вісник Начіонального університету біоресурсів 
i природокористування України. Серія Технологія виробництва і переробки продукції тваринництва, вип. 223, с. 35-40. http://nbuv.gov.ua/UJRN/nvnau_tevppt_2015_223_6

Hilgert-Moreira, S., Nascher, C., Callegari-Jacques, S., Blochtein, B. 2013. Pollen resources and trophic niche breadth of Apis mellifera and Melipona obscurior (Hymenoptera, Apidae) in a subtropical climate in the Atlantic rain forest of southern. Brazil. Apidologie, vol. 45, no. 1, p. 129-141. DOI: 10.1007/ s13592-013-0234-5

Holzschuh, A., Steffan-Dewenter, I., Kleijn, D., Tscharntke, T. 2007. Diversity of flower-visiting bees in cereal fields: effects of farming system, landscape composition and regional context. Journal of Applied Ecology, vol. 44, no. 1, p. 41-49. DOI: 10.1111/j.1365-2664.2006.01259.x

Naug, D. 2009. Nutritional stress due to habitat loss may explain recent honeybee colony collapses. Biological Conservation, vol. 142, p. 2369-2372. DOI: 10.1016/j.biocon.2009.04.007

Novytska, A., Adamchuk, L., Nikolaieva, N. 2016. Acer L. bee pollen morphological features. Науковий вісник Національного університету біоресурсів і природокористування України. Серія: Технологія виробництва і переробки продукції тваринничтва, вип. 250, с. 147-157. http://nbuv.gov.ua/UJRN/ nvnau_tevppt_2016_250_21

Redina, N.M., Adamchuk, L.O., Nikolaieva, N.V., Brindza, J. 2016. Morphological characteristics of bee pollen obtained from Brassica napus L. Scientific Messenger of LNU of Veterinary Medicine and Biotechnologies, vol. 18, no. 2, (68), p. 73-78. DOI:10.15421/nvlvet6814

Адамчук, Л.О., Акульонок, O.І. 2016. Морфологічні особливості бджолиного обніжжя з Salix L. Науковий вісник НУБіП України. Серія: Технологія виробництва і переробки продукції тваринництва, вип. 250, с. 105-113. 